\title{
Nitrogenase Synthesis in Klebsiella pneumoniae: Comparison of Ammonium and Oxygen Regulation
}

\author{
By ROBERT R. EADY, RAFICK ISSACK, CHRISTINA KENNEDY, \\ JOHN R. POSTGATE AND HOWARD D. RATCLIFFE* \\ Agricultural Research Council, Unit of Nitrogen Fixation, University of Sussex, \\ Brighton BN19QJ
}

(Received 7 October 1977)

\begin{abstract}
Rates of nitrogenase synthesis by Klebsiella pneumoniae were measured by pulse-labelling organisms with a mixture of ${ }^{14} \mathrm{C}$-labelled amino acids followed by sodium dodecyl sulphate gel electrophoresis and autoradiography. Populations from an $\mathrm{NH}_{4}{ }^{+}$-repressed, $\mathrm{SO}_{4}{ }^{2-}$ limited chemostat $\left(0.46 \mathrm{mg}\right.$ dry wt ml $\left.{ }^{-1}\right)$, when released from $\mathrm{NH}_{4}{ }^{+}$repression, simultaneously synthesized detectable quantities of the three nitrogenase polypeptides $45 \mathrm{~min}$ before acetylene-reducing activity was observed. Exposure of populations synthesizing nitrogenase to air or $\mathrm{NH}_{4}{ }^{+}\left(200 \mu \mathrm{g} \mathrm{N} \mathrm{ml}^{-1}\right)$ repressed synthesis of both component proteins simultaneously, the rate initially decreasing by half in 11 to $12 \mathrm{~min}$; in the presence of $\mathrm{NH}_{4}{ }^{+}$ a second slower phase with an approximate half-life of $30 \mathrm{~min}$ was observed. With $5 \% \mathrm{O}_{2}$ in $\mathrm{N}_{2}$ the half-lives for the decreases in the rates of synthesis were $30 \mathrm{~min}$ for the Fe protein and $33 \mathrm{~min}$ for the Mo-Fe protein. Oxygen also repressed nitrogenase in a glutamine synthetase constitutive derivative of $K$. pneumoniae (strain sK24) which escapes $\mathrm{NH}_{4}{ }^{+}$ repression. Regulation of nitrogenase by $\mathrm{O}_{2}$ may therefore be independent of glutamine synthetase.
\end{abstract}

\section{INTRODUCTION}

Nitrogen fixation by the facultative anaerobe Klebsiella pneumonide occurs only under anaerobic conditions (Pengra \& Wilson, 1958) or at very low dissolved $\mathrm{O}_{2}$ tensions (Klucas, 1972; Hill, 1975, 1976a,b). Chemostat populations fix $\mathrm{N}_{2}$ at dissolved $\mathrm{O}_{2}$ tensions between 2 and $10 \mathrm{mmHg}$ but not at $15 \mathrm{mmHg}$, and Klucas (1972) suggested that a high respiratory rate at low dissolved $\mathrm{O}_{2}$ tension as reported by Harrison \& Loveless (1971) and Harrison \& Pirt (1967) decreased the dissolved $\mathrm{O}_{2}$ tension to a permissive level for nitrogenase synthesis. The inability of $K$. pneumoniae to fix $\mathrm{N}_{2}$ under aerobic conditions must in part be due to inactivation of its $\mathrm{O}_{2}$-sensitive nitrogenase, but $\mathrm{O}_{2}$, like $\mathrm{NH}_{4}{ }^{+}$, may also repress nitrogenase synthesis as claimed by St John, Shah \& Brill (1974).

In this paper we report a study of $\mathrm{O}_{2}$ as a regulator of nitrogenase synthesis in K. pneumoniae and present evidence, using a mutant in which nitrogenase synthesis is $\mathrm{NH}_{4}{ }^{+}-$ constitutive, that regulation by $\mathrm{O}_{2}$ differs mechanistically from regulation by $\mathrm{NH}_{4}{ }^{+}$.

\section{METHODS}

Organism and culture. The $K$. pneumoniae strains used in this work were the wild-type strain M5a1, in which nitrogenase synthesis is repressed by $\mathrm{NH}_{4}^{+}$, and strain SK-24 (Shanmugam \& Valentine, 1975), a double mutant lacking glutamate synthase activity in which both nitrogenase and glutamine synthetase activities are derepressed in the presence of $\mathrm{NH}_{4}{ }^{+}$. The strains were maintained at $20^{\circ} \mathrm{C}$ in air on $2 \%(\mathrm{w} / \mathrm{v})$ nutrient agar slopes and subcultured monthly. For strain sK-24, approx. $0 \cdot 1 \%(\mathrm{w} / \mathrm{v})$ glutamine was included in the agar.

* Present address: Shell Biosciences Laboratory, Sittingbourne Research Centre, Sittingbourne, Kent ME9 8AG. 
The medium and conditions used for the growth of strain $\mathrm{M}^{\mathrm{a}} 1 \mathrm{in} \mathrm{SO}_{4}{ }^{2-}$-limited continuous culture were those of Tubb \& Postgate (1973), except that the glucose concentration was decreased to $10 \mathrm{~g} \mathrm{l}^{-1}$ and $\mathrm{NH}_{4} \mathrm{Cl}$ was included at a concentration $\left(0.25 \mathrm{~g}^{-1}\right)$ just sufficient to repress nitrogenase synthesis. The chemostat was operated at a dilution rate of $0.1 \mathrm{~h}^{-1}$ which gave a population of $0.46 \mathrm{mg} \mathrm{dry} \mathrm{wt} \mathrm{ml-1}$. The presence of $\mathrm{NH}_{4}{ }^{+}$in the supernatant from the culture vessel was determined by the method of Chaney \& Marbach (1962).

Batch cultures of strain SK-24 were grown on the same medium as used for chemostat culture, except that the $\mathrm{Na}_{2} \mathrm{SO}_{4}$ concentration was increased 10-fold, and L-glutamine $\left(100 \mu \mathrm{g} \mathrm{ml}^{-1}\right)$ and $\left(\mathrm{NH}_{4}\right)_{2} \mathrm{SO}_{4}\left(1 \mathrm{mg} \mathrm{ml}^{-1}\right)$ were included. Cultures were established by inoculating $100 \mathrm{ml}$ of the sterilized medium in $250 \mathrm{ml}$ conical flasks with about $0 \cdot 2 \mathrm{ml}$ of an $18 \mathrm{~h}$ nutrient broth culture and grown under $\mathrm{N}_{2}$ at $30{ }^{\circ} \mathrm{C}$ on a rotary shaker; they were harvested after about $40 \mathrm{~h}$.

Expression of nitrogenase activity. Samples of strain M5a1 from a fully-repressed $\mathrm{SO}_{4}{ }^{2-}$-limited continuous culture were collected anaerobically under $\mathrm{N}_{2}$, centrifuged at $4000 \mathrm{~g}$ for $10 \mathrm{~min}$, and the pellet was resuspended at $30^{\circ} \mathrm{C}$ in derepression medium (half the original volume) previously sparged with $\mathrm{N}_{2}$ for $15 \mathrm{~min}$. This medium was of the same composition as the growth medium in the chemostat except that it contained no $\mathrm{NH}_{4}{ }^{+}$and the $\mathrm{SO}_{4}{ }^{2-}$ concentration was increased 10-fold so as to be non-limiting. Derepressing cultures $\left(520 \mu \mathrm{g}\right.$ protein $\left.\mathrm{ml}^{-1}\right)$ were incubated at $30^{\circ} \mathrm{C}$ in acid-washed tubes $(15 \times 1.5 \mathrm{~cm})$ capped with Suba seals and bubbled with humidified $\mathrm{N}_{2}\left(80 \mathrm{ml} \mathrm{min}^{-1}\right)$. Gas was passed into the culture through a hypodermic needle immersed in the medium, a shorter needle in the gas headspace allowing gas exit. Samples for measurement of nitrogenase activity or for radioactive labelling were removed at intervals with syringes.

To investigate the effect of $\mathrm{NH}_{4}{ }^{+}$or $\mathrm{O}_{2}$ on nitrogenase synthesis, cultures were derepressed for 4 to $5 \mathrm{~h}$ after which time nitrogenase formed a substantial proportion of the protein being synthesized. The cultures, derived from the same chemostat populations, were then exposed to $\mathrm{O}_{2}$ or $\mathrm{NH}_{4}{ }^{+}$and the rate of synthesis of nitrogenase was measured by pulse-labelling with a mixture of ${ }^{14} \mathrm{C}$-labelled amino acids as described below.

Radioactive labelling. Samples $(2 \mathrm{ml})$ were removed from the derepression vessel and injected into $\mathrm{Ar}$ filled acid-washed test tubes incubated at $30^{\circ} \mathrm{C}$, sealed with Suba seals and containing a mixture of ${ }^{14} \mathrm{C}$ labelled amino acids (CFB 104; The Radiochemical Centre, Amersham) to give a final concentration of $2.5 \mu \mathrm{Ci} \mathrm{ml}^{-1}$. Uptake of radioactive material was stopped after $4 \mathrm{~min}$ by addition of unlabelled Casamino acids (Difco) to a final concentration of $1 \mathrm{mg} \mathrm{ml}^{-1}$. The organisms were harvested by centrifuging at $4000 \mathrm{~g}$ for $10 \mathrm{~min}$, washed in $4 \mathrm{ml}$ of saline phosphate $[0.85 \%(\mathrm{w} / \mathrm{v}) \mathrm{NaCl}$ in $75 \mathrm{~mm}$-phosphate buffer $\mathrm{pH} 7 \cdot 2]$ containing Casamino acids $\left(5 \mathrm{mg} \mathrm{m}^{-1}\right)$, collected by centrifugation and frozen by immersing the centrifuge tubes in liquid nitrogen. At this stage the labelled organisms could be stored at $-20^{\circ} \mathrm{C}$.

Electrophoresis and autoradiography. The pelleted organisms were resuspended in $0.25 \mathrm{ml}$ of Ortec gel sample buffer (see below) containing $2 \%$ (w/v) sodium dodecyl sulphate (SDS) and $5 \%(\mathrm{w} / \mathrm{v}) \beta$-mercaptoethanol, then heated in a boiling water bath for 5 to $10 \mathrm{~min}$. To measure radioactivity incorporated into acidinsoluble material, $10 \mu \mathrm{l}$ of the extract was applied to a $2 \mathrm{~cm}$ square of Whatman 3MM paper which was then immersed in ice-cold trichloroacetic acid $(5 \%, w / v)$ for $15 \mathrm{~min}$. The paper was rinsed for $5 \mathrm{~min}$ in ethanol and then in acetone and dried. The dried paper was placed in a vial with $6 \mathrm{ml}$ of scintillation fluid (NE23; Nuclear Enterprises, Beenham, Berkshire) and the radioactivity was measured in a scintillation counter (Nuclear Enterprises 8310).

Volumes of SDS extract containing approximately 100000 c.p.m. were applied to $8 \mathrm{~mm}$-wide sample wells in $1.5 \mathrm{~mm}$-thick polyacrylamide slab gels. The discontinuous gel buffer system used was that described in the Ortec manual (Ortec 4200 electrophoresis system, Ortec, Oak Ridge, Tennessee, U.S.A.) except that $0.1 \%$ SDS was included in both the gel and electrode buffers, and the latter also contained 2 mM-EDTA. In this work the electrode buffer contained SDS (Koch-Light, batch no. 40134) to ensure resolution of both subunits of $\mathrm{Kp} 1$ (Kennedy et al., 1976). A maximum current of $40 \mathrm{~mA}$ was used during electrophoresis.

After electrophoresis, the gel was dried in a slab gel drier (Pharmacia GSD-14) and exposed to a Kodirex $\mathrm{X}$-ray film for 45 to $90 \mathrm{~h}$. The films were scanned with a Fisons Vitatron microdensitometer and the peaks were measured by cutting out and weighing to obtain relative values of radioactive intensity. Under these conditions the intensity of the bands obtained from microdensitometer tracings was proportional to the number of counts applied to the gel. It is estimated that this method will detect the three nitrogenase polypeptides if present at a minimum of about $2 \%$ each of total proteins synthesized.

Enzyme assays. Nitrogenase activity of $K$.pneumoniae was measured essentially as described by Hill (1976b), except that $1 \mathrm{ml}$ of culture was assayed in an $8 \mathrm{ml}$ serum bottle. Glutamine synthetase [L-glutamate: ammonia ligase (ADP-forming); EC 6.3.1.2] was measured in intact organisms as described by Bender et al. (1977). 


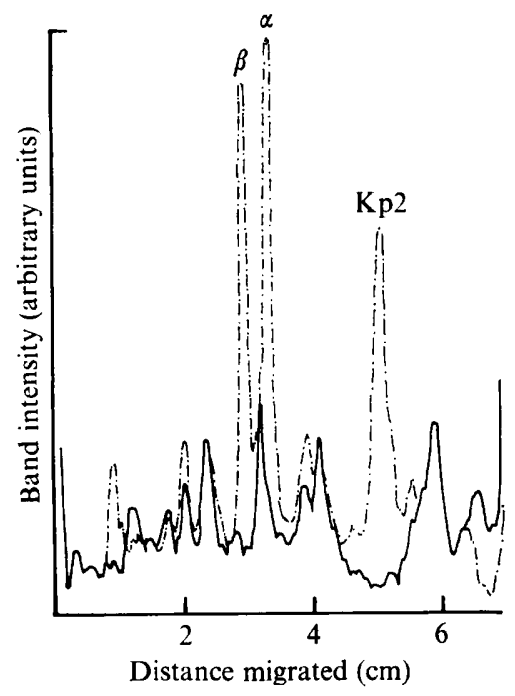

Fig. 1. Microdensitometer traces of autoradiographs of SDS gels of extracts prepared from $K$. pneumoniae $\mathrm{m} 5 \mathrm{a} 1$ grown under conditions where nitrogenase synthesis was repressed by $\mathrm{NH}_{4}^{+}$

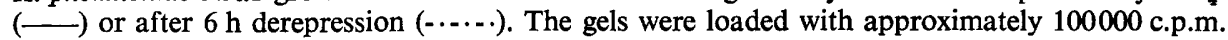
of incorporated acid-insoluble ${ }^{14} \mathrm{C}$ and after electrophoresis were exposed to X-ray film for $45 \mathrm{~h}$. The autoradiographs were scanned at $2 \mathrm{~cm} \mathrm{~min}^{-1}$ using a Fisons Vitatron densitometer with minimum damping.

\section{RESULTS}

Autoradiographs of SDS gels of protein synthesized by $K$. pneumoniae in a pulse-labelling experiment under conditions where nitrogenase was either repressed or derepressed, showed clear differences. The Mo-Fe protein of $K$. pneumoniae nitrogenase $(\mathrm{Kp} 1)$ comprises two types of subunits of approx. mol. wt 50000 and 60000 , present in equal numbers (Eady et al., 1972). Under the appropriate conditions of SDS electrophoresis these subunits can be separated, and have been shown to be different polypeptides (Kennedy et al., 1976). In this paper, the 50000 and $60000 \mathrm{~mol}$. wt subunits will be referred to as the $\alpha$ and $\beta$ subunits of $\mathrm{Kp} 1$ respectively. The Fe protein of nitrogenase $(\mathrm{Kp} 2)$ has a single type of subunit of mol. wt 37000 (Eady et al., 1972). Figure 1 shows typical microdensitometer scans of gels from organisms under conditions where nitrogenase was repressed by $\mathrm{NH}_{4}{ }^{+}$and from organisms during derepression. The labelling pattern was sufficiently different to enable the three nitrogenase polypeptides to be easily identified by comparison with the migration of highly-purified nitrogenase proteins. The identity and significance of the few other bands which changed in intensity is not known.

\section{Derepression of nitrogenase}

When washed organisms from a chemostat culture were resuspended in $\mathrm{NH}_{4}{ }^{+}$-free medium and bubbled with $\mathrm{N}_{2}$, acetylene reduction was first detected after about $2 \mathrm{~h}$. The enzymic activity increased rapidly and showed a linear increase with time from about 3 to $5 \mathrm{~h}$ (Fig. 2). At intervals during derepression, samples were removed from the culture and pulse-labelled with ${ }^{14} \mathrm{C}$-labelled amino acids as described in Methods. Autoradiography of the SDS gels showed nitrogenase polypeptides to be present $1 \mathrm{~h}$ after the start of derepression, and then to increase as a proportion of the total radioactivity incorporated into protein for the next $2 \mathrm{~h}$. After this time the rate of synthesis increased only very slowly, whereas the rate of acetylene reduction was increasing rapidly (Fig. 2). The nitrogenase polypeptides constituted a substantial proportion of the proteins synthesized: usually $30 \%$, with a range of 12 to $40 \%$. The reasons for this variation are not clear since the organisms originated from 


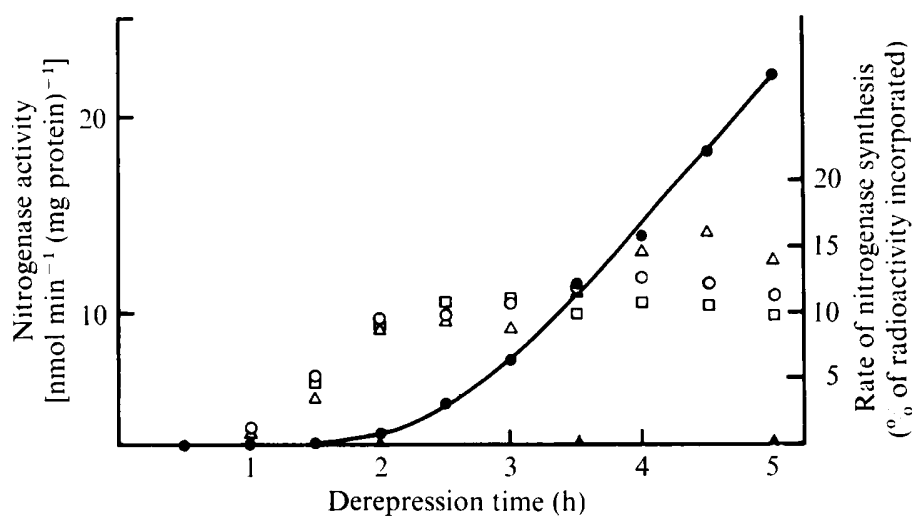

Fig. 2. Derepression of nitrogenase activity in K. pneumoniae M5a1. At zero time organisms were washed free of $\mathrm{NH}_{4}{ }^{+}$, and rates of nitrogenase synthesis and nitrogenase activity were measured at various times as described in Methods: $\bullet$, acetylene reducing activity; $\square, \alpha$ subunit of $\mathrm{Kpl}$; $O, \beta$ subunit of $\mathrm{Kp} 1 ; \triangle$, subunit of $\mathrm{Kp} 2 ; \boldsymbol{\Delta}$, acetylene reducing activity in the presence of $\mathrm{NH}_{4}{ }^{+}$ ( $200 \mu \mathrm{g} \mathrm{N} \mathrm{ml}^{-1}$ added at zero time) or when $5 \%(\mathrm{v} / \mathrm{v}) \mathrm{O}_{2}$ in $\mathrm{N}_{2}$ was bubbled through the culture.
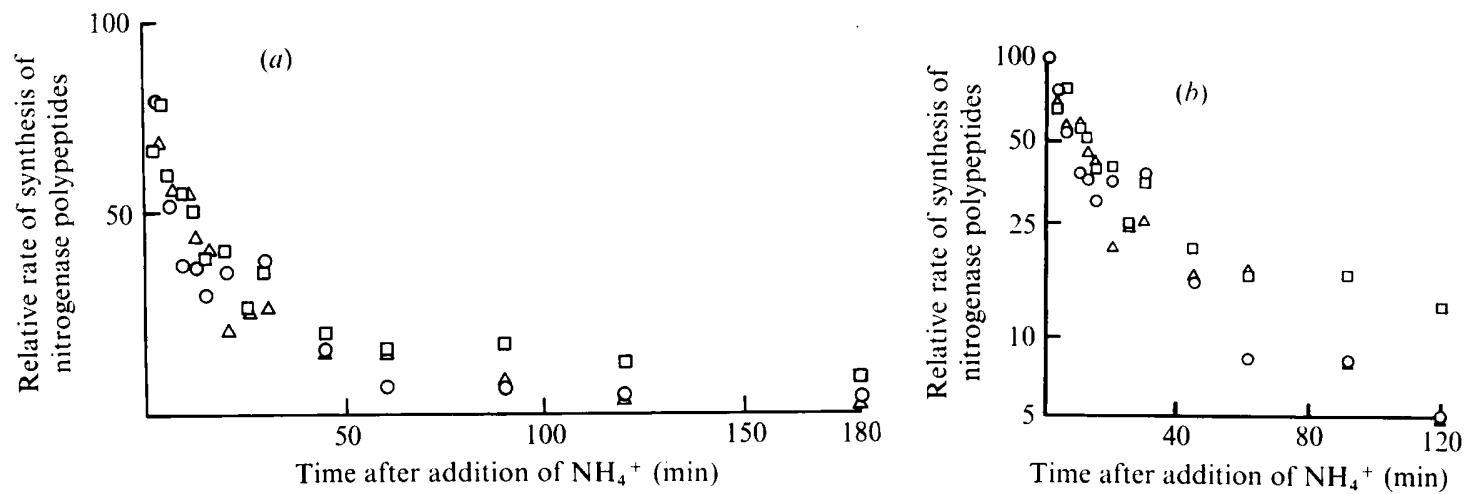

Fig. 3(a). Effect of $\mathrm{NH}_{4}{ }^{+}$on nitrogenase synthesis in $K$. pneumoniae $\mathrm{M} 5 \mathrm{a} 1$. A derepressed culture was exposed to ammonium acetate $\left(200 \mu \mathrm{g} \mathrm{N} \mathrm{ml}^{-1}\right)$ and samples were removed at intervals for measurement of nitrogenase synthesis: $\square, \alpha$ subunit of $\mathrm{Kp} 1 ; O, \beta$ subunit of $\mathrm{Kp} 1 ; \triangle$, subunit of $\mathrm{Kp} 2$. (b) Semi-logarithmic plot of the same dcta. In both $(a)$ and $(b)$, rates of synthesis of nitrogenase polypeptides are expressed as a percentage of the initial proportion of radioactivity incorporated into nitrogenase.

a continuous culture which remained in a steady state. The correlation between acetylenereducing activity and intensity of the nitrogenase bands was therefore rather variable.

\section{Effect of ammonium ions on nitrogenase synthesis}

When ammonium acetate $\left(200 \mu \mathrm{g} \mathrm{N} \mathrm{ml}^{-1}\right)$ was added to a comparable sample from the chemostat, nitrogenase remained repressed and no acetylene reduction (Fig. 2) or synthesis of nitrogenase polypeptides was observed. The addition of $\mathrm{NH}_{4}{ }^{+}\left(200 \mu \mathrm{g} \mathrm{N} \mathrm{ml}^{-1}\right)$ to a derepressing culture of $K$. pneumoniae resulted in an immediate decrease in the intensity of nitrogenase bands on autoradiograms (Fig. $3 a$ ). A semi-logarithmic plot of these data (Fig. $3 b$ ) gave an approximate half-life of $11 \mathrm{~min}$ for the initial decay of rate of synthesis of both $\mathrm{Kp} 1$ and $\mathrm{Kp} 2$, which was followed by a decreased rate of decay at longer times,with an approximate half-life of $30 \mathrm{~min}$. 


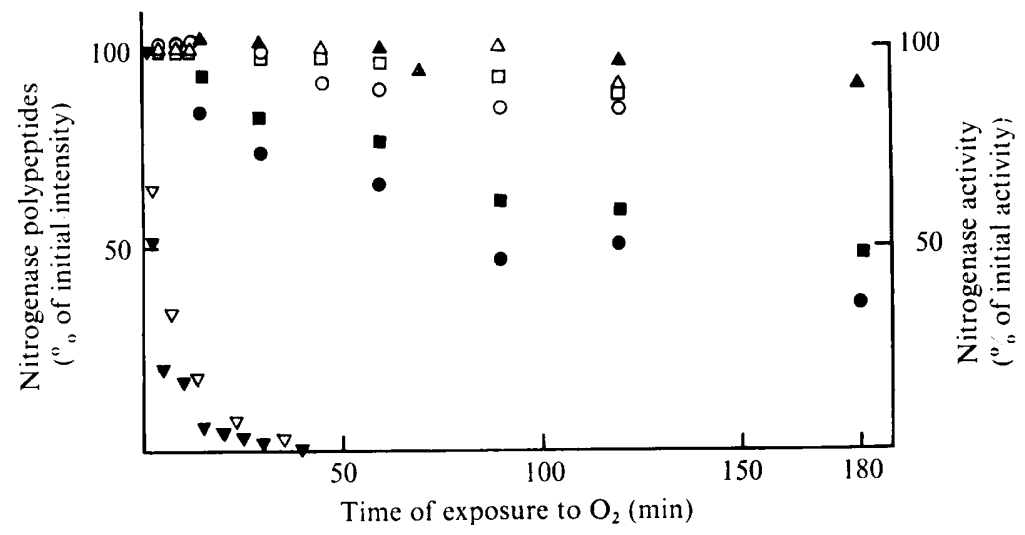

Fig. 4. Effect of $\mathrm{O}_{2}$ on pre-formed nitrogenase and on acetylene reducing activity. Cultures of $K$. pneumoniae $\mathrm{M} 5 \mathrm{a} 1$ were bubbled with $5 \%(\mathrm{v} / \mathrm{v}) \mathrm{O}_{2}$ in $\mathrm{N}_{2}$ (open symbols) or air (closed symbols) in the presence of chloramphenicol $\left(1 \mathrm{mg} \mathrm{ml}^{-1}\right)$, and nitrogenase was monitored by autoradiography of SDS gels of extracts: $\square, \boldsymbol{\square}, \alpha$ subunit of $\mathrm{Kp1} ; \bigcirc, \boldsymbol{O}, \beta$ subunit of $\mathrm{Kp} 1 ; \Delta, \Delta$, subunit of $\mathrm{Kp} 2$; $\nabla, \nabla$, acetylene reducing activity. When acetylene reduction was to be measured, chloramphenicol was omitted and nitrogenase activity was determined as described in Methods.
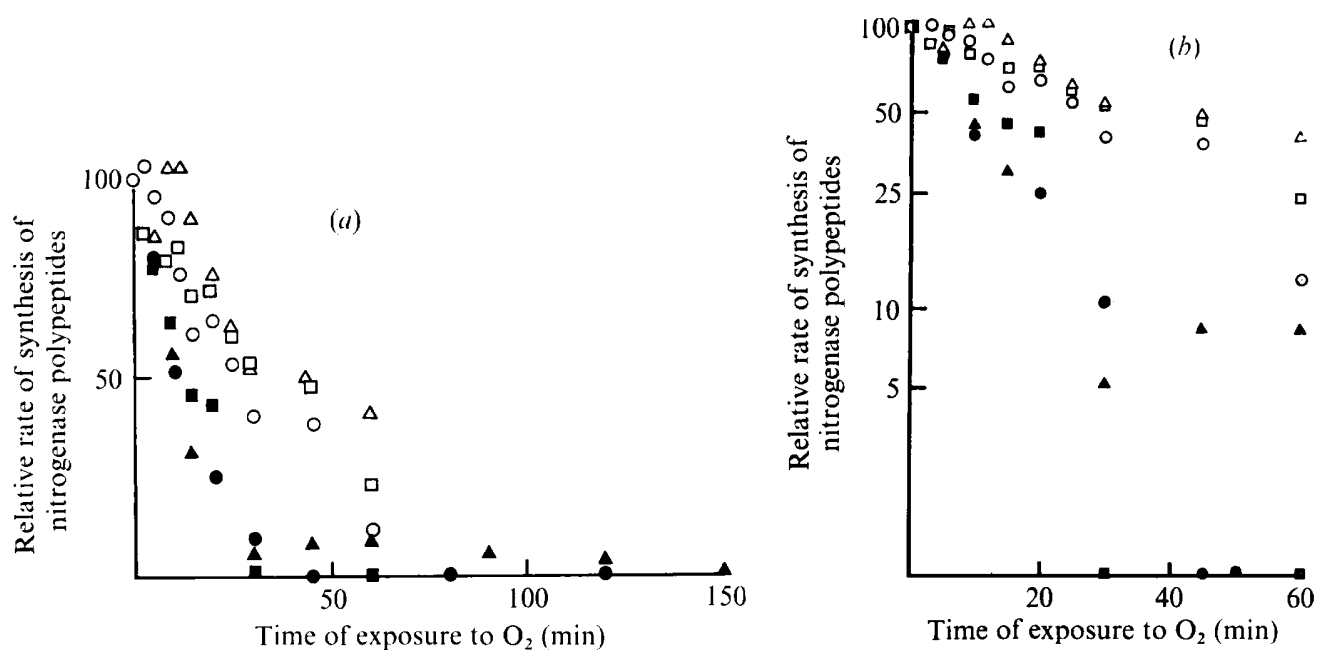

Fig. 5(a). Effect of $\mathrm{O}_{2}$ on nitrogenase synthesis in $K$. pneumoniae M5a1. Nitrogenase synthesis was measured by autoradiography of SDS gels of extracts prepared from derepressed organisms exposed to $5 \%(\mathrm{v} / \mathrm{v}) \mathrm{O}_{2}$ in $\mathrm{N}_{2}$ (open symbols) or air (closed symbols) for various periods: $\square, \square, \alpha$ subunit of $\mathrm{Kp} 1 ; \bigcirc, \Theta, \beta$ subunit of $\mathrm{Kp} 1 ; \Delta, \Delta$, subunit of $\mathrm{Kp} 2$. (b) Semi-logarithmic plot of the same data. In both $(a)$ and $(b)$ rates of synthesis of nitrogenase polypeptides are expressed as a percentage of the initial proportion of radioactivity incorporated into nitrogenase.

\section{Effect of oxygen on pre-formed nitrogenase}

As a preliminary to studying $\mathrm{O}_{2}$ as a repressor, it was necessary to determine the stability of pre-formed nitrogenase to $\mathrm{O}_{2}$. Bacteria were therefore removed from the chemostat to the derepression medium and after $4 \mathrm{~h}$ the organisms were pulse-labelled with a mixture of ${ }^{14} \mathrm{C}$-labelled amino acids and then exposed to air or $5 \%(\mathrm{v} / \mathrm{v}) \mathrm{O}_{2}$ in $\mathrm{N}_{2}$ in the presence of chloramphenicol $\left(1 \mathrm{mg} \mathrm{ml}^{-1}\right)$. Samples were removed at intervals for autoradiography of SDS gels. The nitrogenase bands were unaffected by $5 \% \mathrm{O}_{2}$ over $30 \mathrm{~min}$ and only a small decrease in their intensity occurred during the next $1.5 \mathrm{~h}$ (Fig. 4). When the cultures were bubbled with air, the intensity of the nitrogenase bands immediately but slowly decreased. $\mathrm{Kp} 1$ showed a greater sensitivity towards air than did $\mathrm{Kp} 2$, which was only slowly degraded. 
Table 1. Effect of $\mathrm{NH}_{4}{ }^{+}$or oxygen on nitrogenase synthesis by the $\mathrm{NH}_{4}{ }^{+}$-constitutive mutant $\mathrm{K}$. pneumoniae $\mathrm{SK}-24$

Batch cultures of sK-24 were centrifuged and the organisms were resuspended in derepression medium supplemented with glutamine $\left(100 \mu \mathrm{g} \mathrm{ml}^{-1}\right)$. Three $10 \mathrm{ml}$ cultures were incubated under the conditions indicated below. After $6 \mathrm{~h}$ the rate of acetylene reduction was measured. Samples were also removed and pulse-labelled with a mixture of ${ }^{14} \mathrm{C}$-labelled amino acids for measurement of nitrogenase synthesis as described in Methods.

\begin{tabular}{|c|c|c|c|c|}
\hline \multirow[b]{3}{*}{ Culture conditions } & \multirow[b]{3}{*}{$\begin{array}{l}\text { Nitrogenase activity } \\
{\left[\mathrm{nmol} \mathrm{C}_{2} \mathrm{H}_{2} \text { reduced }\right.} \\
\left.\text { min }^{-1}(\mathrm{mg} \text { protein })^{-1}\right]\end{array}$} & \multicolumn{3}{|c|}{$\begin{array}{l}\text { Rate of nitrogenase synthesis } \\
\text { (\% of total proteins) }\end{array}$} \\
\hline & & \multicolumn{2}{|c|}{$\mathrm{Kp} 1$} & \multirow[t]{2}{*}{$\mathrm{Kp} 2$} \\
\hline & & $\stackrel{\alpha}{\alpha}$ & $\begin{array}{c}\beta \\
\text { subunit }\end{array}$ & \\
\hline $\begin{array}{l}\mathrm{N}_{2} \text { plus } \mathrm{NH}_{4}^{+}\left(200 \mu \mathrm{g} \mathrm{N} \mathrm{ml}^{-1}\right) \\
\mathrm{N}_{2} \\
\text { Air }\end{array}$ & $\begin{array}{c}10 \cdot 9 \\
11 \\
0\end{array}$ & $\begin{array}{l}5 \\
7 \\
0\end{array}$ & $\begin{array}{l}5 \cdot 6 \\
5 \cdot 9 \\
0\end{array}$ & $\begin{array}{l}9 \cdot 4 \\
8 \cdot 5 \\
0\end{array}$ \\
\hline
\end{tabular}

Bubbling with either air or $5 \% \mathrm{O}_{2}$ resulted in an immediate decrease in nitrogenase activity of intact organisms as measured by the acetylene-reduction assay (Fig. 4).

\section{Effect of oxygen on nitrogenase synthesis}

When $5 \% \mathrm{O}_{2}$ was bubbled through a derepressing population of $K$. pneumoniae, there was a lag of about 12 min before an effect on the rate of synthesis of $\mathrm{Kp} 2$ was observed (Fig. $5 \mathrm{a}$ ). The decrease in synthesis rate of both subunits of $\mathrm{Kpl}$ appeared to be parallel and was initiated earlier than the decrease in the rate of $\mathrm{Kp} 2$ synthesis. A semi-logarithmic plot of the data (Fig. $5 b$ ) gave approximate half-lives of $33 \mathrm{~min}$ for $\mathrm{Kp} 1$ synthesis and $30 \mathrm{~min}$ for Kp2 synthesis. When the culture was bubbled with air, no lag was observed before the rate of nitrogenase synthesis decreased. The rate of decrease was more rapid than that observed with $5 \% \mathrm{O}_{2}$ : the half-life was about 12 min and no synthesis of $\mathrm{Kp} 1$ subunits was detected after $30 \mathrm{~min}$. In contrast, synthesis of $\mathrm{Kp} 2$ continued at a decreased rate up to $180 \mathrm{~min}$.

As the effect of $\mathrm{O}_{2}$ in decreasing the intensity of the nitrogenase bands occurred more rapidly than could be accounted for by the degradation of $\mathrm{O}_{2}$-damaged proteins (compare Fig. 4 and Fig. 5), $\mathrm{O}_{2}$ must have repressed nitrogenase synthesis.

\section{Effect of oxygen and $\mathrm{NH}_{4}{ }^{+}$on an $\mathrm{NH}_{4}{ }^{+}$-constitutive mutant of $\mathrm{K}$. pneumoniae}

Glutamine synthetase mediates repression of nitrogenase by $\mathrm{NH}_{4}{ }^{+}$in $K$. pneumoniae (Tubb, 1974; Streicher et al., 1974). Klebsiella pneumoniae strain sK-24 lacks glutamate synthase activity and synthesis of glutamine synthetase and nitrogenase occurs at derepressed levels in the presence of $\mathrm{NH}_{4}{ }^{+}$. If repression by $\mathrm{O}_{2}$ is also mediated by glutamine synthetase this strain would be expected to escape $\mathrm{O}_{2}$ repression. The effects of $\mathrm{N}_{2}, \mathrm{~N}_{2}$ plus $\mathrm{NH}_{4}{ }^{+}$and $20 \% \mathrm{O}_{2}$ in $\mathrm{N}_{2}$ (air) on nitrogenase synthesis and activity are shown in Table 1 . After $6 \mathrm{~h}$ in derepression medium supplemented with glutamine $\left(100 \mu \mathrm{g} \mathrm{ml}^{-1}\right)$, the rates of nitrogenase activity and synthesis were similar in organisms under $\mathrm{N}_{2}$ or $\mathrm{N}_{2}$ plus $\mathrm{NH}_{4}{ }^{+}$, but organisms exposed to $20 \% \mathrm{O}_{2}$ during this time had no nitrogenase activity or nitrogenase synthesizing ability. In cultures exposed to $\mathrm{O}_{2}$, nitrogenase activity was undetectable after 45 min. Figure 6 shows typical autoradiographs of extracts of these organisms which indicate that no synthesis of the nitrogenase proteins occurred in organisms which had been exposed to $\mathrm{O}_{2}$. 
(a)

(b)

$(c)$

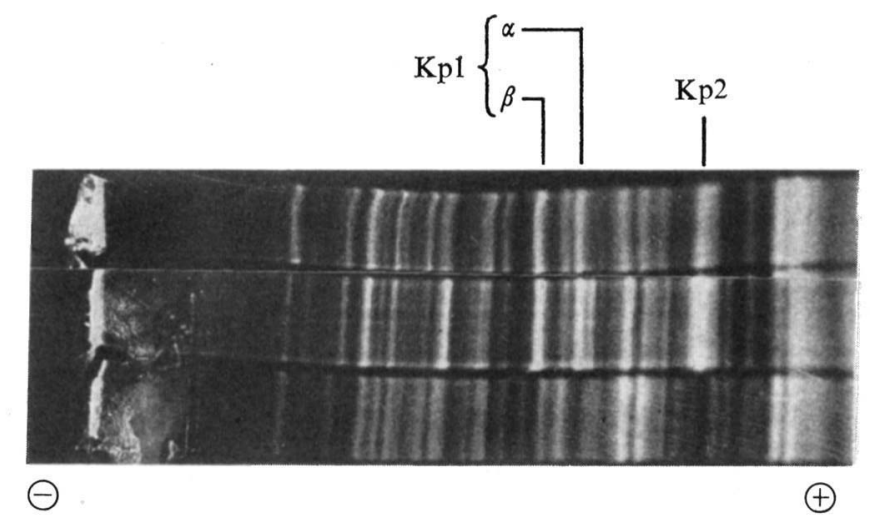

Fig. 6. Autoradiograms showing the effects of $\mathrm{NH}_{4}{ }^{+}$and $\mathrm{O}_{2}$ on nitrogenase synthesis in $K$. pneumoniae SK-24. Cultures of SK-24 were grown in derepression medium supplemented with glutamine $\left(100 \mu \mathrm{g} \mathrm{ml}^{-1}\right)$. After $6 \mathrm{~h}$ samples were removed and pulse-labelled with a mixture of ${ }^{14} \mathrm{C}$-labelled amino acids and then subjected to SDS eletrophoresis. Cultures were grown under $(a) \mathrm{N}_{2}$ plus ammonium acetate $\left(200 \mu \mathrm{g} \mathrm{N} \mathrm{ml}^{-1}\right) ;(b) \mathrm{N}_{2} ;(c)$ air.

\section{Effect of oxygen on glutamine synthetase activity}

The average adenylylation level of glutamine synthetase in intact $K$. pneumoniae M5al was measured by the method of Bender et al. (1977). In this assay hexadecyltrimethylammonium bromide is used to prevent changes in adenylylation occurring during sample manipulation. The specific activities of glutamine synthetase in samples from $\mathrm{NH}_{4}{ }^{+}$-grown and $\mathrm{N}_{2}$-fixing cultures sparged with $\mathrm{N}_{2}$ were 72 and $221 \mathrm{nmol} \gamma$-glutamyl hydroxamate $\mathrm{min}^{-1}$ (mg protein) $)^{-1}$ respectively. When the sparging gas was changed to air the total activity in both cultures increased by approximately $25 \%$ within $45 \mathrm{~min}$, but in neither case did the ratio of biosynthetically active (nonadenylylated) enzyme to total enzyme $(0 \cdot 7$ in both cultures) change significantly.

\section{DISCUSSION}

The lag in expression of nitrogen fixation during derepression. Fleming \& Haselkorn (1974), using a comparable radio-labelling technique, reported synthesis of nitrogenase components long before the appearance of enzymic activity during heterocyst development in Nostoc muscorum. The extreme sensitivity of the acetylene reduction assay for nitrogenase makes it unlikely that the lag is an artefact due to insensitive enzyme assay. Under conditions of derepression, supplies of ATP or of reducing equivalents, both necessary for nitrogenase function, would not be expected to limit nitrogenase activity. A possible explanation is that the lag represents a period in which a specific electron donor protein to nitrogenase, for example a flavodoxin, is synthesized. Under our conditions of electrophoresis, peptides of molecular weight 20000 and below would remain undetected. The lag is unlikely to be due to the dissociation of $\mathrm{Kp} 1$ and $\mathrm{Kp} 2$ at low protein concentrations since complex formation is rapid $\left(K>10^{7} \mathrm{M}^{-1} \mathrm{~s}^{-1}\right.$; Thorneley, 1975) and tight $\left(K_{\text {complex }}=3 \times 10^{7} \mathrm{M}^{-1}\right.$; Thorneley, Eady \& Yates, 1975). The possibility that it is due to the slow assembly of $\mathrm{Kp} 1$ or $\mathrm{Kp} 2$ from their respective subunits cannot be excluded since nothing is known about these processes.

The lag in repression of nitrogenase synthesis by oxygen. The lag observed before $5 \% \mathrm{O}_{2}$ has an effect on nitrogenase synthesis may be attributed to the time taken for the dissolved $\mathrm{O}_{2}$ tension to reach a repressive level. Measurement of the rates of increase in dissolved $\mathrm{O}_{2}$ indicates that this occurs relatively slowly at the gas flow rates and culture densities used in our experiments (S. Hill, personal communication). Further work will be required to correlate dissolved $\mathrm{O}_{2}$ tension with the regulation of nitrogenase synthesis, but the dif- 
ferential repressive effect of $\mathrm{O}_{2}$ on $\mathrm{Kp} 1$ and $\mathrm{Kp} 2$ may indicate a greater sensitivity to dissolved $\mathrm{O}_{2}$ of the processes leading to synthesis of $\mathrm{Kp} 1$.

Stability of nitrogenase proteins in vivo. Our results using chloramphenicol agree with the observations of St John et al. (1974) who demonstrated that on exposure of intact organisms to air, both the enzymic activity and the antigenic cross-reacting material of $\mathrm{Kp} 1$ decreased faster than those of $\mathrm{Kp} 2$. This contrasts with the $\mathrm{O}_{2}$-sensitivity of the highly-purified nitrogenase components, since $\mathrm{Kp} 2$, with a half-life of $45 \mathrm{~s}$ in air, is at least 10 times more sensitive to inactivation than Kp1 (Eady et al., 1972).

Kinetics and mechanisms of oxygen repression. The half-lives of the reduction in rates of nitrogenase synthesis under maximum $\mathrm{O}_{2}$ or $\mathrm{NH}_{4}{ }^{+}$repression were similar (11 to $12 \mathrm{~min}$ ) and the lag in the effect of $5 \% \mathrm{O}_{2}$ has been attributed above to slow diffusion of oxygen to the appropriate regulatory site. Nevertheless, this kinetic similarity may not reflect a similar mode of action at the molecular level, since our experiments with the $\mathrm{NH}_{4}{ }^{+}$-constitutive strain show that $\mathrm{O}_{2}$ represses nitrogenase synthesis despite the fact that glutamine synthetase activity remains little changed on exposure of the culture to $\mathrm{O}_{2}$.

The experiments reported here cannot distinguish between effects of $\mathrm{O}_{2}$ on transcription or on translation since only completed nitrogenase polypeptides are measured. Such effects might be distinguished by pulse-labelling experiments in which organisms are exposed to $\mathrm{O}_{2}$ in the presence of differential inhibitors of transcription and translation. Loss of nitrogenase activity in cultures exposed to $\mathrm{NH}_{4}{ }^{+}$compared with loss of activity after exposure to chloramphenicol or rifampicin suggest that $\mathrm{NH}_{4}{ }^{+}$acts at the transcriptional level (Tubb \& Postgate, 1973; Collmer \& Lamborg, 1976). The nif gene cluster is located near the genes for histidine biosynthesis in $K$. pneumoniae and may include as many as three genes involved in regulation (nifA, nifL and nifE, see Kennedy \& Dixon, 1977). It is conceivable that one of these gene products mediates repression of nitrogenase synthesis by $\mathrm{O}_{2}$.

We are indebted to Professor R. C. Valentine for supplying strain sK-24 of K. pneumoniae and to Dr Susan Hill for useful discussions.

\section{REFERENCES}

Bender, R. A., Janssen, K. A., Resnick, A. D., Blumenberg, M., Foor, F. \& MagasaniK, B. (1977). Biochemical parameters of glutamine synthetase from Klebsiella aerogenes. Journal of Bacteriology 129, 1001-1009.

Chaney, A. L. \& Marbach, E. P. (1962). Modified reagents for determination of urea and ammonia. Clinical Chemistry 8, 130-132.

Collmer, A. \& Lamborg, M. (1976). Arrangement and regulation of the nitrogen fixation genes in Klebsiella pneumoniae studied by derepression kinetics. Journal of Bacteriology 126, 806-813.

Eady, R. R., Smith, B. E., CooK, K. A. \& Postgate, J. R. (1972). Nitrogenase of Klebsiella pneumoniae: purification and properties of the component proteins. Biochemical Journal 128, 655-675.

Fleming, H. \& Haselkorn, R. (1974). The programme of protein synthesis during heterocyst differentiation in nitrogen-fixing blue-green algae. Cell 3, 159-170.

Harrison, D. E. F. \& Loveless, J. E. (1971). The effect of growth conditions on respiratory activity and growth efficiency in facultative anaerobes grown in chemostat culture. Journal of General Microbiology 68, 35-43.

Harrison, D. E. F. \& PIRT, S. J. (1967). The influence of dissolved oxygen concentration on the respiration and glucose metabolism of Klebsiella aerogenes during growth. Journal of General Microbiology 46, 193-211.

HiLl, S. (1975). Acetylene reduction by Klebsiella pneumoniae in air related to colony dimorphism on low fixed nitrogen. Journal of General Microbiology 91, 207-209.

HILL, S. (1976a). Influence of atmospheric oxygen concentration on acetylene reduction and efficiency of nitrogen fixation in intact Klebsiella pneumoniae. Journal of General Microbiology 93, 335-345.

HiLl, S. (1976b). The apparent ATP requirement for nitrogen fixation in growing Klebsiella pneumoniae. Journal of General Microbiology 95, 297-312.

Kennedy, C. \& Dixon, R. (1977). The nitrogen fixation cistrons of Klebsiella pneumoniae. In Genetic Engineering for Nitrogen Fixation, Basic Life Sciences, vol. 9, pp. 51-66. New York: Plenum Publishing Corp.

Kennedy, C., EADY, R. R., Kondorosi, E. \& Klavans ReKosh, D. (1976). The molybdenumiron protein of Klebsiella pneumoniae: evidence for non-identical subunits from peptide mapping. Biochemical Journal 155, 383-389.

Kiucas, R. (1972). Nitrogen fixation by Klebsiella 
grown in the presence of oxygen. Canadian Journal of Microbiology 18, 1845-1850.

Pengra, R. M. \& Wilson, P. W. (1958). Physiology of nitrogen fixation by Aerobacter aerogenes. Journal of Bacteriology 75, 21-25.

Shanmugam, K. T. \& Valentine, R. C. (1975). Microbial production of ammonium ion from nitrogen. Proceedings of the National Academy of Sciences of the United States of America 72, 136139.

St John, R. T., Shah, V. K. \& Brill, W. J. (1974). Regulation of nitrogenase synthesis by oxygen in Klebsiella pneumoniae. Journal of Bacteriology 119, 266-269.

Streicher, S. L., Shanmugam, K. T., Asubel, F., Morandi, C. \& GoldberG, R. B. (1974). Regulation of nitrogen fixation in $K$. pneumoniae: evidence for a role of glutamine synthetase as a regulator of nitrogenase synthesis. Journal of Bacteriology 129, 815-821.

ThORNELEY, R. N. F. (1975). Nitrogenase of Klebsiella pneumoniae. A stopped-flow study of magnesium-adenosine triphosphate-induced electron transfer between the component proteins. Biochemical Journal 145, 391-396.

Thorneley, R. N. F., EAdY, R. R. \& YATES, M. G. (1975). Nitrogenases of Klebsiella pneumoniae and Azotobacter chroococcum. Complex formation between the component proteins. Biochimica et biophysica acta 403, 269-284.

Tuвb, R. S. (1974). Glutamine synthetase and ammonium regulation of nitrogenase synthesis in Klebsiella. Nature, London 251, 481-485.

Tubb, R. S. \& Postgate, J. R. (1973). Control of nitrogenase synthesis in Klebsiella pneumoniae. Journal of General Microbiology 79, 103-117. 